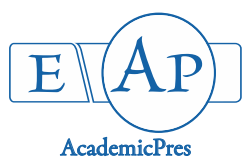

Thapliyal M et al. (2021)

Notulae Scientia Biologicae

Volume 13, Issue 4, Article number 11044

DOI: $10.15835 / \mathrm{nsb} 13411044$

Research Article

\title{
Seed germination response of Indian wild pear (Pyrus pashia) to gibberellic acid treatment and cold storage
}

\author{
Manisha THAPLIYAL*, Namitha N. KALIYATHAN, \\ Kanupriya RATHORE
}

\author{
Forest Research Institute, Forest Tree Seed Laboratory, Dehradun 248006, India; \\ manishathapliyal98@gmail.com (*correspondingauthor);namithafri@gmail.com; kanupriyarathore16@gmail.com
}

\begin{abstract}
Knowledge of seed germination behaviour of different seed sources of tree species is useful in selecting the most responsive and adaptive ones for propagation and germplasm conservation. The wild Himalayan pear (Pyrus pashia Buch-Ham ex D. Don) produces highly nutritious edible fruits that are consumed by local communities. The populations of the species are threatened due to exploitation and lack of adequate conservation programmes. The study was conducted to examine the germination response of $P$. pashia seeds from two sources (S1-Champawat and S2-Pithoragarh) in Uttarakhand state of India, to different $\mathrm{GA}_{3}$ treatment and also to assess the viability and longevity of the seeds in cold storage $\left(5^{\circ} \mathrm{C}\right)$ for three years. In both sources germination percent (GP) increased significantly under $\mathrm{GA}_{3}$ treatment and speed of germination was also enhanced (reduction in mean germination time). In Source 1, GP increased under all GA $\mathrm{G}_{3}$ application, highest being 94\% under $\mathrm{GA}_{3} 500$ ppm treatment. In Source 2, GP of seeds doubled under 100 ppm GA 3 treatment while its higher concentrations did not improve the germination. However, the differences observed in germination between the seed sources could be due to differences in the dormancy levels and/or sensitivity to dormancy breaking elements across their geographical range. Thus, exogenous application of $\mathrm{GA}_{3}$ is suggested for enhancing the germination in seeds of $P$. pashia. Seeds responded to cold storage by increased germination with duration, i.e. highest after three years in storage, indicating that the seeds got the required chilling treatment for overcoming dormancy.
\end{abstract}

Keywords: conservation; $\mathrm{GA}_{3}$ treatment; physiological dormancy; seed source; storage; wild Himalayan pear

\section{Introduction}

Pyrus pashia commonly known as Indian Pear, wild Himalayan Pear, belongs to the family Rosaceae. It is a moderate-sized deciduous tree with branches dark-brown in colour and often spiny. Leaves are simple, glabrous and ovate-lanceolate in shape (Kanjilal, 1928). Fruit of $P$. pashia is Pome, brown in colour, pulpy and contains approximately five seeds per fruit. Leaves of $P$. pashia are used as fodder, wood is utilised as fuel and for making small agricultural implements. Fruits are edible, highly nutritious and are included in the diet by

Received: 10 Aug 2021. Received in revised form: 02 Nov 2021. Accepted: 05 Nov 2021. Published online: 11 Nov 2021.

From Volume 13, Issue 1, 2021, Notulae Scientia Biologicae journal uses article numbers in place of the traditional method of continuous pagination through the volume. The journal will continue to appear quarterly, as before, with four annual numbers. 
local people. They provide multiple ecosystem services as a source of nutrition, pollination, genetic variation for breeding programs, and even of valuable income for people living around them (Powell et al., 2013).

The wild populations of $P$. pashia are distributed in India, Nepal, Bhutan, Afghanistan, Pakistan, Thailand, China, and Indochina at an altitude of 750-2500 m. In India, the species are found in Himalayan region and north-eastern regions (Troup, 1975). Pyrus species are threatened with about $85 \%$ pear varieties lost in $19^{\text {th }}$ century (Sindelar, 2002). Furthermore, due to various insect pests, pathogens and abiotic stresses, valuable and highly resistant pear germplasm has been lost (Fowler and Mooney, 1990). Therefore, more efforts to conserve the genetic resources of these species must be made. The genetic diversity can be best preserved by systematic collection for establishing field germplasm banks and long-term storage of seeds in Seedbanks.

Pyrus species are widely cultivated in many parts of the world but physiological dormancy associated with seed causes irregular germination in the species. Dormancy plays a major role in regulating germination in many tree species. Dormancy release is regulated by a combination of environmental and endogenous signal with both synergistic and competing effects. The balance of abscisic acid (ABA); gibberellin (GA) levels and sensitivity is a major, but not the sole, regulator of dormancy status (Finkelstein et al., 2008). Pear seeds belong to Rosaceae family usually show dormancy at maturity and require $2-3$ months at $0-7^{\circ} \mathrm{C}$ temperature in a moist, well-aerated medium to break dormancy (Hartmann et al., 1990), which is similar to the requirements for apple seeds (Lewak, 2011). Gibberellic acid (GA) activates the production of $\alpha$-amylase, proteolytic enzymes, nucleases, etc., leading to loss of seed dormancy and promotion of seed germination (Dominguez et al., 2004; Mrva et al., 2006). Studies evaluating the exogenous application of gibberellic acid have shown to relieve certain types of dormancy, including physiological dormancy, thermo-dormancy and photo dormancy, and to replace partially or fully the necessary cold treatments in different plants (Hartmann et al., 1997).

Seed viability can be extended by cold or dry storage at seed moisture content below 5\% (Huang et al., 2003). Cold storage reduces or prevents the effects of ageing was indicated by the slower rate of damage caused by low temperature (Spano et al., 2006). The aim of our study was to examine the germination response of $P$. pashia seeds from two sources (Champawat and Pithoragarh) of Uttarakhand state in India, to different $\mathrm{GA}_{3}$ treatment (soaking in 100, 300, 500 and $700 \mathrm{ppm}$ solutions for 24 hours) and also to assess the viability and longevity of the seeds stored at moisture content of $8 \%$ at $5{ }^{\circ} \mathrm{C}$.

\section{Materials and Methods}

\section{Seed material}

Mature fruits of Pyrus pashia were collected in October 2017 from natural stands at two locations namely Champawat Forest Range (Source 1 or S1) and Pithoragarh Forest Range (Source 2 or S2) in Uttarakhand state of India. Geographical coordinates of the two sources of the species are presented in Table 1. Fruits were brought to Forest Tree Seed Laboratory of the Institute at Dehradun in permeable bags. The species produces pulpy fruits with seeds consisting of hard endocarp. Fruits were macerated, de-pulped and washed under running tap water to extract the seeds. Extracted seeds were shade- dried in ambient conditions for 3-4 days.

Table 1. Geographical locations and altitudes of the two seed sources of Pyrus pashia

\begin{tabular}{|l|c|c|}
\hline \multicolumn{1}{|c|}{ Site of seed collection } & Co-ordinates & Altitude (m asl) \\
\hline \multirow{2}{*}{ Source1 Champawat } & $29^{0} 32^{\prime} 50.2^{\prime \prime} \mathrm{N}$ & 1937 \\
& $80^{0} 11^{\prime} 07.1{ }^{\prime \prime} \mathrm{E}$ & 2540 \\
\hline Source 2 & $29^{0} 58^{\prime} 15.3{ }^{\prime \prime} \mathrm{N}$ & $250^{\prime}$ \\
Pithoragarh & $80^{0} 39^{\prime} 16.3^{\prime \prime} \mathrm{E}$ & \\
\hline
\end{tabular}


Moisture content of the seeds

The moisture content of the seed was determined by low constant oven dry method at $103 \pm 1^{\circ} \mathrm{C}$ for 17 hrs (ISTA, 2010) in 4 replicates of 10 seeds each. Moisture content was determined on the fresh weight basis (\%) using the formula:

$$
M C=\frac{(F w-D w)}{F w} \times 100
$$

where MC is the moisture content, Fw is the initial fresh weight of the replicate and Dw is the dry weight.

\section{Germination test}

Germination test was conducted on fresh seeds from both seed sources. The experiment was designed in completely randomised block in four replications of 25 seeds each, which were placed on moist Whatman filter paper in sterile Petri dishes $\left(15 \mathrm{~cm}\right.$ dia.) and kept in a seed germinator (NSW New Delhi, India) at $25^{\circ} \mathrm{C}$ temperature (ISTA, 2010) with 8 hours photoperiod. A seed was considered to have germinated when the radical was $1 \mathrm{~cm}$ long. The observations on seed germination were taken every day (except weekends) up to 28 days from the date of sowing (ISTA, 2010). Germination parameters such as germination percent; Mean Germination Time (Orchard, 1977) and Germination value (Djavanshir and Pourbeik, 1976) of the species were measured as per the standard methods. Germination percent of seed was expressed as:

Germination percentage $(G)=$ total number of seed germinated at end of germination test/total number of seeds placed for germination test $\times 100$.

MGT - a parameter used for monitoring the speed of germination was calculated as:

Mean germination time $(\mathrm{MGT})=\Sigma \mathrm{Fx} / \Sigma \mathrm{F}$; where $\mathrm{F}$ is the number of seeds germinated on day $\mathrm{x}$.

Germination value was expressed as $\sum \mathrm{DGS} / \mathrm{N}$ x (Final cumulative Germination Percent/10); where DGS is daily germination speed which is calculated by dividing cumulative germination percent by the number of days since beginning the test, $\mathrm{N}$ is number of counts and 10 is constant through germination test.

\section{Gibberellic acid treatment}

For observing the effect of gibberellic acid pre-treatment on the germination and its speed, seeds from both sources were pre-treated with $\mathrm{GA}_{3}$ at different concentrations; seeds were soaked in $100 \mathrm{ppm}, 300 \mathrm{ppm}$, $500 \mathrm{ppm}$ and 700 ppm $\mathrm{GA}_{3}$ solution for 24 hours before placing for germination experiment. For each test separate seed samples were used. Untreated seeds served as control.

\section{Seed storage}

Fresh seed of $P$. pashia from both sources after quality evaluation (seed germination test) were desiccated to $8 \%$ moisture content from initial $11 \%$ using silica gel in 1:1 ratio. Desiccated seeds were thereafter stored at $5 \pm 1{ }^{\circ} \mathrm{C}$ temperature in air-tight plastic boxes in a seed storage chamber and their viability was evaluated through germination test every six months, up to a period of three years (results only presented for yearly germination) to evaluate the germination pattern and longevity of seeds under storage conditions.

\section{Statistical analysis}

Statistical analysis of cumulative germination data was performed with SPSS Statistics for Windows, version 16.0' (SPSS Inc., Chicago, Ill., USA). Statistical analysis was performed using GLM multivariate ANOVA for testing the significance of treatment ( 4 levels for $\mathrm{GA}_{3}$ and 3 for storage duration), population (two levels) and their interactions on GP, MGT and GV. All tests were analysed at a significance level of $\alpha=$ 0.025 . 


\section{Results}

Germination response of $P$. pashia seeds to $G A_{3}$ treatment

Untreated seeds (control) exhibited a GP of $62 \%$ in S1 and $15 \%$ GP in S2. This difference could be due to the degree of dormancy related to different seed sources. In S1, MGT was recorded as 12.37 days and in S2 MGT was recorded as 15.45 days (Figure 1) indicating significantly lower germination and slow speed of germination in seeds of Source 2. GV was observed as 12.02 in S1 and much lower (0.46) in S2 (Figure 2).

$\mathrm{GA}_{3}$ treatment of seeds significantly increased the germination percent against that in untreated seeds. Highest GP (94\%) was observed in the seeds pretreated with $\mathrm{GA}_{3} 500 \mathrm{ppm}$ followed by the ones treated with $300 \mathrm{ppm}$ (93\%), $700 \mathrm{ppm}(92 \%)$ and 100 ppm (86\%). Seeds pretreated with $\mathrm{GA}_{3}$ at 100 ppm resulted in highest GP (31\%) in Source 2 followed by 700 ppm (29\%), 300 ppm (25\%) and 500 ppm (23\%) (Figure 1). Mean germination time (MGT) which indicates the speed of germination ranged from 5.4 to 6.6 days in $S 1$ and 7.4 to 10.6 days in S2. Germination was fastest (lowest MGT) in the seeds treated with 700 ppm GA $_{3}$ in S1 and 500 ppm GA 3 in S2. Highest MGT (slow speed of germination) was observed in the seeds treated with $100 \mathrm{ppm} \mathrm{GA}$ in both the sources (Figure 1) which means that seeds took longer to complete the germination. GV ranged from 42.6 to 60.4 in S1 and 2.4 to 4.8 in S2, which was significantly lower than that of seeds of S1 as the germination of seeds was significantly lower impacting the overall value of germination. Highest GV was recorded in seeds treated with 700 ppm $\mathrm{GA}_{3}$ in both sources (Figure 2).

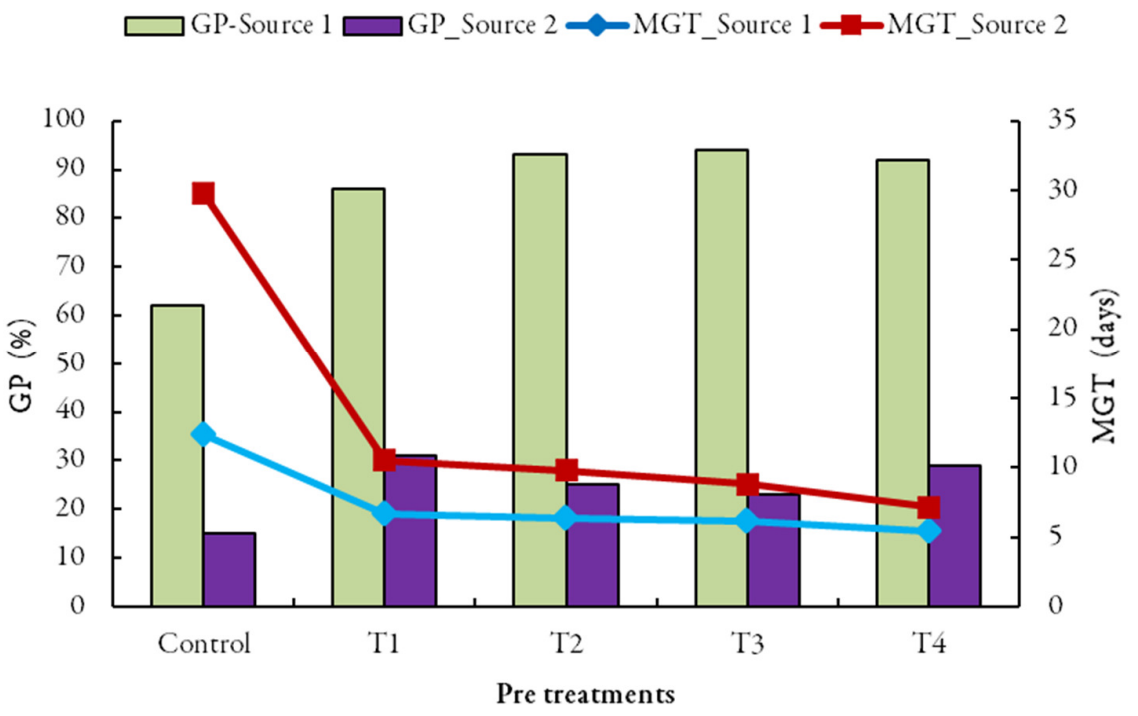

Figure 1. Germination Percent (GP) and Mean Germination Time (MGT) of Pyrus pashia seeds from Source 1 (Champawat) and Source 2 (Pithoragarh) after pre-soaking seeds in T1-100 ppm, T2-300 ppm, T3-500 ppm and T4-700 ppm GA 3 solution 


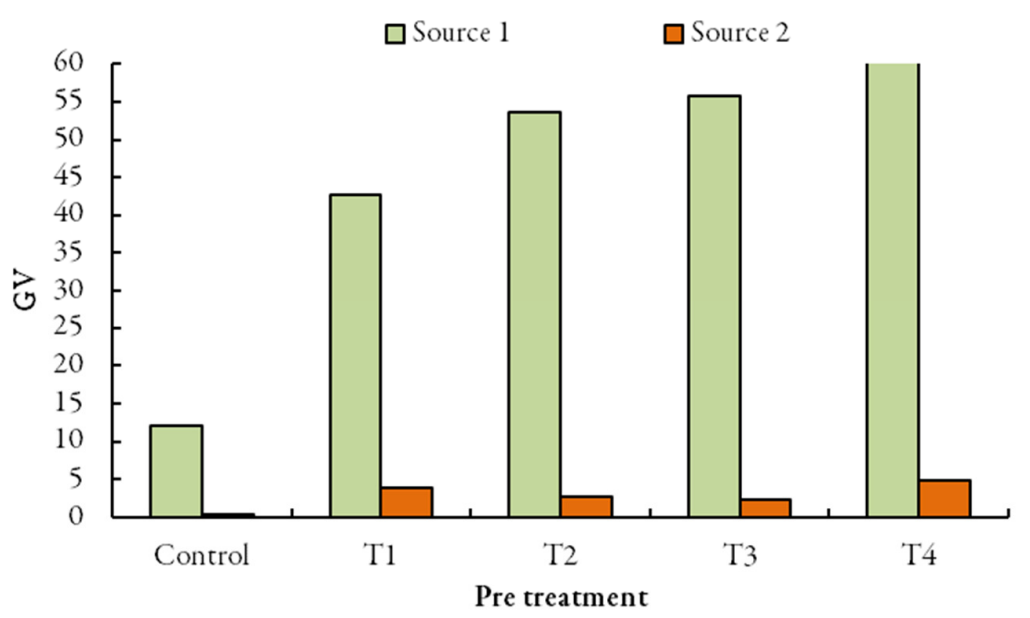

Figure 2. Germination value (GV) of Pyrus pashia seeds from Source 1 (Champawat) and Source 2 (Pithoragarh) in pre-soaked seeds in T1-100 ppm, T2-300 ppm, T3-500 ppm and T4-700 ppm GA 3 solution

\section{Germination response of seed to cold storage condition}

Study assessed the seed germination behaviour of stored seed for three years. In S1, germination percent of seed was $55 \%$ after one year of storage, which increased to $64.5 \%$ after second year and further to $82.5 \%$ in third year while in case of seeds of other source (S2), GP was $12.25 \%, 17.33 \%$ after first and second year respectively, that doubled to $34.75 \%$ after three years of storage. In both sources, highest GP was observed in third year of storage as compared to first year (Figure 3) which clearly indicated that the seeds required cold treatment which they got and responded favourably by increased GP. In S1, lowest and highest MGT was 9.4 and 12.8 days. Lowest MGT in seed was recorded in the second year of storage that exhibited faster speed of germination in the seeds. In S2, lowest MGT of 1.4 days was recorded in the third year and highest was 8.9 days after the first year of storage (Figure 3). Highest GV was recorded in seeds stored for three years in both sources (Figure 4) as germination was also highest in them.

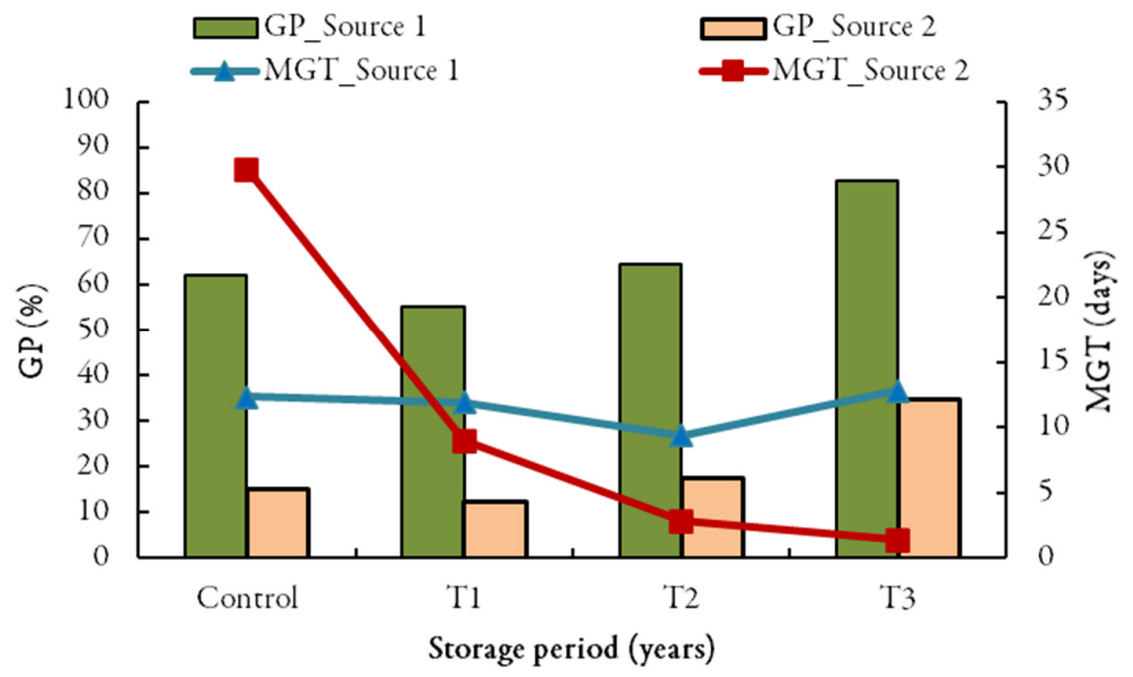

Figure 3. Germination Percent (GP) and Mean Germination Time (MGT) of Pyrus pashia seeds from Source 1 (Champawat) and Source 2 (Pithoragarh) in cold storage $\left(5^{\circ} \mathrm{C}\right)$ after T1- 1 year storage, T2- 2 years storage and T3- 3 years storage duration 


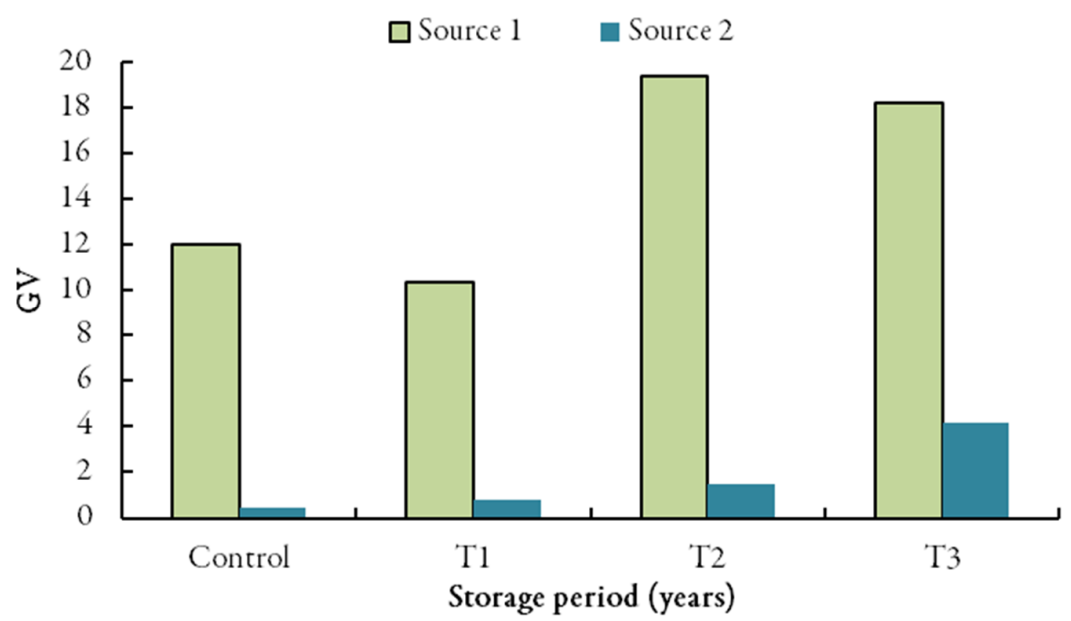

Figure 4. Germination Value (GV) of Pyrus pashia seeds from Source 1 (Champawat) and Source 2 (Pithoragarh) in cold storage $\left(5^{\circ} \mathrm{C}\right)$ after T1- 1 year storage, T2- 2 years storage and T3- 3 years storage duration

The effect of $\mathrm{GA}_{3}$ treatment (various concentrations) on germination percent and mean germination time of seeds of $P$. pashia was significantly different $(\mathrm{p}<0.025)$, highest germination occurred in seeds presoaked in 500ppm $\mathrm{GA}_{3}$ solution in $S 1$ and those in $100 \mathrm{ppm}$ in $S 2$. Similarly, the effect of population on germination percent and mean germination time of seed was significantly different $(\mathrm{p}<0.025)$ but the effect of interaction between treatment and population on germination percent and mean germination time of seed was not significantly different $(\mathrm{p}>0.025)$ (Table 2$)$. There was significant effect of treatments, population and interaction between treatment and population on germination value meaning that the germination value which is an index of expression of speed and totality of germination, under different treatments differed in the two populations significantly $(\mathrm{p}<0.025)$.

Table 2. Summary of General Linear Model (GLM) multivariate analysis for testing significant effects of seed sources and treatment

\begin{tabular}{|c|c|c|c|c|c|c|}
\hline Variable & Source of variation & $\mathrm{DF}$ & SS & MS & F-value & $\mathrm{p}$-value \\
\hline \multirow{5}{*}{ GP } & TRT & 7 & 7030.6 & 1004.4 & 10.268 & 0.000000 \\
\hline & Population & 1 & 48662.9 & 48662.9 & 497.519 & 0.000000 \\
\hline & TRT ${ }^{*}$ Population & 7 & 1649.2 & 235.6 & 2.409 & 0.033846 \\
\hline & Error & 48 & 4694.9 & 97.8 & & \\
\hline & Total & 63 & 62037.6 & & & \\
\hline \multirow{5}{*}{ MGT } & TRT & 7 & 434.888 & 62.127 & 16.997 & 0.000000 \\
\hline & Population & 1 & 54.199 & 54.199 & 14.829 & 0.000348 \\
\hline & TRT*Population & 7 & 65.042 & 9.292 & 2.542 & 0.026118 \\
\hline & Error & 48 & 175.444 & 3.655 & & \\
\hline & Total & 63 & 729.573 & & & \\
\hline \multirow{5}{*}{ GV } & TRT & 7 & 6885.88 & 983.70 & 29.0088 & 0.000000 \\
\hline & Population & 1 & 15826.24 & 15826.24 & 466.7086 & 0.000000 \\
\hline & TRT*Population & 7 & 5700.22 & 814.32 & 24.0139 & 0.000000 \\
\hline & Error & 48 & 1627.70 & 33.91 & & \\
\hline & Total & 63 & 30040.03 & & & \\
\hline
\end{tabular}

Treatment includes pre-soaking in $100 \mathrm{ppm} ; 300 \mathrm{ppm} 500 \mathrm{ppm}$; and 700 ppm GA 3 solution and cold storage for 1, 2 and 3 years on germination percent (GP), mean germination time (MGT) and germination value (GV) of P. pashia seeds from Source 1 (Champawat) and Source 2 (Pithoragarh) in Uttarakhand state in India. $(\mathrm{P}<0.025)$ denote significant difference on seed source and treatment independently and combined effect of both on GP, MGT and GV. 


\section{Discussion}

Fresh seeds of $P$. pashia from both sources yielded lesser germination (without any pretreatment) as compared to $\mathrm{GA}_{3}$ treatment. It was under $\mathrm{GA}_{3}$ treatment, highest GP was exhibited in the seed pre-treated with 500 ppm in S1 while it was in 100 ppm in S2. Exogenous application of $\mathrm{GA}_{3}$ breaks dormancy and accelerates seed germination in many Rosaceae members. Gibberellins stimulate germination by inducing hydrolytic enzymes that weaken the barrier tissues such as endosperm, seed coat, inducing mobilization of seed storage reserves, and stimulating the expansion of embryo (Finkelstein et al., 2008). Kumar et al. (1988) studied germination in seeds of $P$. pashia using $0.5 \%, 1.2 \%$ and $5 \%$ ethanol and $-3 \log \mathrm{M},-5 \log \mathrm{M}$ and $-7 \log \mathrm{M}$ GA Unstratified seeds of $P$. pashia responded with the germination of $60 \%$ in $-7 \log \mathrm{M} \mathrm{GA}_{3}$ and $90 \%$ in $5 \%$ ethanol treatment.

Fogle (1958) reported that soaking seeds of sweet cherry for twenty-four hours in gibberellin at a concentration of $100 \mathrm{ppm}$ immediately after collection substitutes for two or three months of the after-ripening period. Pillay et al., (1965) reported that soaking seeds in gibberellin at a concentration of 100 ppm increases the rate of germination and partially replaces the chilling requirements in Prunus avium and Prunus mahaleb. According to Donoho and Walker (1957) seed treatment with gibberellin could replace the low-temperature requirement to some extent in Prunus persica. Treatment of seeds with $\mathrm{GA}_{3}$ may substitute for cold stratification was also reported for Prunus persica, Myrica pensylvanica (Macdonald, 1993), Arbutus unedo (Smiris et al., 2006), Jasione supina subsp. supine (Güleryüz, 2021). In our study also, germination of seeds significantly increased under $\mathrm{GA}_{3}$ treatment exhibiting the replacement of chilling requirement of seeds for overcoming physiological dormancy which the seeds get during the winters in their natural habitat.

Germination percent of seeds increased from 55 to $82.5 \%$ in accession 1 which was an increase of $27 \%$ and from 12.25 to $34.75 \%$ i.e. almost three times in S2 from first year to third year. It shows that seeds of $P$. pashia got the required chilling treatment during cold storage that resulted in subsequent increase in the GP and reduction in MGT. According to Baskin and Baskin (1988) some species can come out of dormancy during dry storage but a relative humidity of $30-40 \%$ is required for them to do so. Highest germination was observed in the seeds stored for 3 years in both sources. Storage of seeds in the air-dried state at low temperature for afterripening between $1{ }^{\circ} \mathrm{C}$ to $10{ }^{\circ} \mathrm{C}$ or $2^{\circ} \mathrm{C}$ to $5^{\circ} \mathrm{C}$ for periods of some months to several years have been reported to break dormancy for certain forest and fruit trees (Crocker, 1948; Stokes, 1965). Highest germination of $P$. pashia seeds after three years in stored conditions indicate that seeds in cold storage $\left(\right.$ at $5{ }^{\circ} \mathrm{C}$ storage temp, $8 \%$ seed moisture content) required several months to reach full ripening, breaking dormancy and accelerate germination. Generally, desiccation plays a crucial role in the after-ripening process, which prepares the seeds for germination. This suggests that one of the functions of the desiccation process is preparation for germination (Wawrzyniak et al., 2020).

Storage conditions and duration significantly affect germination percent has been reported in many species. Huang et al. (2003) reported that seed viability can be extended by cold or dry storage at seed moisture content below 5\%. Temporary cold storage under high-moisture conditions enhanced germination in Arbutus unedo (Ana Vasques et al., 2014). Abdelbasit et al. (2012) observed that cold and dry storage increased seed germinability with increasing storage time in Acacia tortilis of three provenances.

A comparative study on $P$. pashia seeds from two seed sources revealed a significant difference on GP, MGT of seed under similar pre-treatments $(\mathrm{p}<0.025)$ but the effect of interaction between treatments and seed source is not significant in both seed sources under similar storage conditions which indicate the difference in quality of seeds collected from different natural ranges. Provenance / seed source studies in forest trees are very important for determining the quality, identifying the best and highly adaptable provenance and for screening the naturally available genetic variation to utilize the best material for maximum productivity and for further breeding programme (Suri, 1984; Shiv Kumar and Banerjee, 1986). Baskin and Baskin (1998) reported that fresh seed collected from various locations can alter the germination characteristics of seed due to different degree of dormancy. Seed from different accessions reported various depth of dormancy due to genotype-by- 
environment interactions in Arabidopsis (Donohue et al., 2005; Vidigal, 2016); Medicago truncatula (Renzi et al., 2020). In the present study also, the initial germination of seeds from Champawat (S1) was 62\% which was more than 4 times that of seeds from Pithoragarh (S2). This could be because of varying dormancy levels in the seeds. Donohue et al. (2005) observed that depth of dormancy is determined genetically as well as by the ambient environment during seed formation. Genetic variation for germination can be detected when genotypes are compared in identical environments. This implies that not only the conditions of the germination test must be identical, but also growth conditions during seed development and storage conditions, including the time that the seeds are stored, must be the same (Bentsink and Koornneef, 2008). Germination responses of a seed vary according to geographical and environmental factors viz. altitude, elevation, soil moisture, soil nutrient, temperature, kind and density of plant cover, degree of habitat disturbance of the seed where the seed matures (Ginwal et al., 2005).

\section{Conclusions}

In the present study, seed from both sources responded to exogenous $\mathrm{GA}_{3}$ applications as well as cold storage while higher seed viability and vigour was exhibited by seed collected from $S 1$ in terms of all germination parameters. Seed source plays an important role for the contribution of germination percent; still further research should be extended to large provenance aligned in this direction for a better characterisation of effect of $\mathrm{GA}_{3}$ and long-term storage on seed germination of Rosaceae members especially species subjected to rapid environmental changes like in Pyrus pashia from different provenances/sources.

\section{Authors' Contributions}

Conceptualization: MT and NNK, Laboratory work and data curation: KR, Technical Supervision: MT and NNK Data analysis and interpretation: MT, NNK and KR, Manuscript writing and review: MT, NNK and KR. All authors read and approved the final manuscript.

\section{Acknowledgements}

The work was supported by the Ministry of Environment, Forest and Climate Change, Government of India (Grant No. 13-17/2012-CAMPA). The authors thank Mr. Raman Nautiyal, Scientist for statistical analysis support to research findings. The authors also thank the anonymous reviewers for critical review of the manuscript for improving its quality.

\section{Conflict of Interests}

The authors declare that there are no conflicts of interest related to this article.

\section{References}

Abdelbasit H, Mahgoup S, Eldoma A (2012). Effect of cold and dry storage on seed viability among three provenances of Acacia tortilis subspecies raddiana and subspecies spirocarpa. International Journal of Advanced Biological Research 2:130-137. 
Baskin CC, Baskin JM (2004). A classification system of seed dormancy. Seed Science Research 14:1-16. https://doi.org/10.1079/SSR2003150

Baskin CC, Baskin, JM (1998). Seeds: Ecology, biogeography and evolution of dormancy and germination. Academic Press, San Diego, California, USA. https://doi.org/10.1023/A:1011465920842

Bentsink L, Koornneef M (2008). Seed dormancy and germination. The Arabidopsis Book/American Society of Plant Biologists, pp 6. https://doi.org/10.1199/tab.0119

Crocker W (1948). Growth of plants. Reinhold Publishing Corporation, New York. https://doi.org/10.1002/jps.3030370918

Djavanshir K, Pourbeik H (1976). Germination value: A new formula. Silvae Genetica 25:79-83.

Domínguez F, Moreno J, Cejudo FJ (2004). A gibberellin-induced nuclease is localized in the nucleus of wheat aleurone cells undergoing programmed cell death. The Journal of Biological Chemistry 279:11530-11536. https://doi.org/10.1074/jbc.M308082200

Donoho CW, Walker DR (1957). Effect of gibberellic acid on breaking of rest period of Eleberta peach. Science 126:11781179. https://doi.org/10.1126/science.126.3284.1178-a

Donohue K, Dorn L, Griffith C, Kim E, Aguilera A, Polisetty CR, Schmitt J (2005). Environmental and genetic influences on the germination of Arabidopsis thaliana in the field. Evolution 596:740-757. https://doi.org/10.1111/j.0014-3820.2005.tb01750.x

Finkelstein R, Reeves W, Ariizumi T, Steber C (2008). Molecular aspects of seed dormancy. Annual Review of Plant Biology 59:387-415. https://doi.org/10.1146/annurev.arplant.59.032607.092740

Fogle HW (1958). Effects of duration of after ripening, gibberellins and other pretreatments on sweet cherry germination and seedling growth. Proceedings of American Society for Horticultural Science 72:129-133. https://doi.org/10.2307/2440115

Fowler C, Mooney P (1990). Shattering food, politics and the loss of genetic diversity. The University of Arizona Press. Tucson, USA.

Ginwal HS, Phartyal SS, Rawat PS, Srivastava RL (2005). Seed source variation in morphology, germination and seedling growth of Jatropha curcas in central India. Silvae Genetica 54:76-80. https://doi.org/10.1515/sg-2005-0012

Güleryüz G, Kırmızı S, Arslan H, Güleryüz E (2021). Breaking of dormancy in the narrow endemic Jasione supina Sieber subsp. supina (Campanulaceae) with small seeds that do not need light to germinate. Acta Botanica Croatica 80:12-17. https://doi.org/10.37427/botcro-2021-009.

Hartmann HT, Kester DE, Davies FT, Jr., Geneve RL (1997). Plant propagation: Principles and Practices. $6^{\text {th }}$ ed. Prentice Hall Upper Saddle River, New Jersey. https://doi.org/10.1016/S0304-4238(97)00085-X

Huang Z, Zhang X, Zheng G, Gutterman Y (2003). Influence of light, temperature, salinity and storage on seed germination of Haxloxylon annodendron. Journal of Arid Environments 55:453-464. https://doi.org/10.1016/S0140-1963(02)00294-X

ISTA (2010). International Rules for Seed Testing. Zurichstr.50, CH-8303 Bassersdorf, Switzerland.

Kanjilal UN (1928). Forest flora of the Chakrata, Dehradun and Saharanpur Forest Divisions. Uttar Pradesh, $3^{\text {rd }}$ ed. Govt. of India Press, Delhi.

Kumar A, Nautiyal MC, Prakash S (1988). Enhancement of pear (Pyrus pashia L.) seed germination by GA and ethanol. Current Science 57:964-966.

Lewak S (2011). Metabolic control of embryonic dormancy in apple seed: seven decades of research. Acta Physiologiae Plantarum 33:1-24. https://doi.org/10.1007/s11738-010-0524-8

Macdonald B (1993). Practical woody plant propagation for nursery growers. $4^{\text {th }}$ edition. Timber Press, Portland, Oregon.

Mrva K, Wallwork M, Mares DJ (2006). Alpha- amylase and programmed cell death in aleurone of ripening wheat grains. Journal of Experimental Botany 57:877-885. https://doi.org/10.1093/jxb/erj072

Orchard T (1977). Estimating the parameters of plant seedling emergence. Seed Science and Technology 5:61-69.

Pillay DTN, Brase KD, Edgerton LJ (1965). Effects of pretreatments, temperature and duration of after ripening of germination of Mazzard and Mahaleb Cherry seeds. American Society for Horticultural Science 86:102-107.

Powell B, Ickowitz A, McMullin S (2013). The role of forests, trees and wild biodiversity for nutrition-sensitive food systems and landscapes. In: Expert background paper for the International Conference on Nutrition, Food and Agriculture Organization of the United Nations. Rome, Italy.

Renzi JP, Duchoslav M, Brus J, Hradilová I, Pechanec V, Václavek T, ... Smýkal P (2020). Physical dormancy release in Medicago truncatula seeds is related to environmental variations. Plants 9:503. https://doi.org/10.3390/plants9040503 
Shiv Kumar P, Banerjee AC (1986). Provenance trail of Acacia nilotica. Journal of Tree Sciences 5:53-56.

Sindelar J (2002). Toward threatened forest tree species preservation on the example of crab apple (Malus sylvestris L.) and wild pear (Pyrus pyraster L. [Burgsdorf]). Zprav Lesnic Vyzk 47:199-203.

Smiris P, Pipinis E, Aslanidou M, Mavrokordopoulou O, Milios E, Kouridakis A (2006). Germination study on Arbutus unedo L. (Ericaceae) and Podocytisus caramanicus Boiss. \& Heldr (Fabaceae). Journal of Biological Research 5:85-91.

Spano C, Buselli RF, Castiglione MR, Bottega S, Grilli I (2006). RNases and nucleases in embryos and endosperms from naturally aged wheat seeds stored in different condition. Journal of Plant Physiology 164:487-495. https://doi.org/10.1016/j.jplph.2006.03.015

Stokes P (1965). Temperature and seed dormancy. In: Ruhland W (Ed). Encyclopedia of Plant Physiology 15(2):746803. Springer, Berlin. https://doi.org/10.1007/978-3-642-50088-6_60

Suri SK (1984). Analytical study of teak provenance test in North Raipur Division of Madhya Pradesh. The Indian Forester 110:345-363.

Timson J (1965). New method of recording germination data. Nature 207:216-217. https://doi.org/10.1038/207216a0

Troup RS (1975). Silviculture of Indian trees (Revised edition). Forest Research Institute Press, Dehradun, India. https://doi.org/10.5962/bhl.title.24363

Vasques A, Vallejo VR, Santos MC, Keizer JJ (2014). The role of cold storage and seed source in the germination of three Mediterranean shrub species with contrasting dormancy types. Annals of Forest Science 71(8):863-872. https://doi.org/10.1007/s13595-014-0395-Z

Vidigal DS, Marques ACSS, Willems LAJ, Buijs G, Méndez-Vigo B, Hilhorst HWM, ... Alonso-Blanco C (2016). Altitudinal and climatic associations of seed dormancy and flowering traits evidence adaptation of annual life cycle timing in Arabidopsis thaliana. Plant Cell and Environment 39:1737-1748. https://doi.org/10.1111/pce.12734

Wawrzyniak M, Michalak M, Chmielarz P (2020). Effect of different conditions of storage on seed viability and seedling growth of six European wild fruit woody plants. Annals of Forest Science 77:58-77. https://doi.org/10.1007/s13595-020-00963-Z
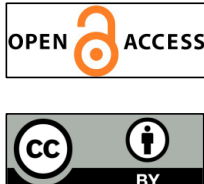

The journal offers free, immediate, and unrestricted access to peer-reviewed research and scholarly work. Users are allowed to read, download, copy, distribute, print, search, or link to the full texts of the articles, or use them for any other lawful purpose, without asking prior permission from the publisher or the author.

License - Articles published in Notulae Scientia Biologicae are Open-Access, distributed under the terms and conditions of the Creative Commons Attribution (CC BY 4.0) License.

(c) Articles by the authors; SHST, Cluj-Napoca, Romania. The journal allows the author(s) to hold the copyright/to retain publishing rights without restriction. 